\title{
RÁdIO E RENOVAÇÃO POLÍTICA EM ELEIÇÃO MAJORITÁRIA: A VITÓRIA ELEITORAL DE PREFEITO/RADIALISTA EM PONTA GROSSA
}

\author{
Emerson Urizzi Cervi \\ Mestre em Sociologia e Política pela UFPR \\ E-mail: ecervi@netbank.com.br
}

\section{Resumo}

$O$ interesse pelo estudo dos efeitos da comunicação de massa nas sociedades contemporâneas, em especial nos processos eleitorais, vem crescendo. Tem sido comum a constatação da existência de um relacionamento de interdependência entre a propagação do discurso político através dos meios de comunicação de massa e o fenômeno do populismo político. O presente trabalho analisa a importância do Rádio para a eleição de prefeito de um radialista/político na cidade de Ponta Grossa. O estudo das características das elites políticas locais, dos efeitos das políticas públicas implantadas e das crises conjunturais pelas quais passaram os eleitores dessa cidade, é possível identificar a origem da aceitação do discurso neopopulista. Sendo assim, pode-se dizer que o fenômeno radialista/político não nasce nas ondas do rádio, mas através delas consegue propagar a idéia mudancista.

Palavras-chave: eleições; neopopulismo; elites políticas; poder local.

Os grandes homens de Estado de todos os tempos e de todos os países consideraram a imaginação popular o sustentáculo do seu poder. 'Tornei-me católico', afirmou Napoleão ao Conselho de Estado, "e acabei com a guerra de Vendeia; tornei-me muçulmano e venci no Egito, tornei-me ultramontano e conquistei os padres na Itália. Se vier a governar um povo de Judeus, reconstruirei o tempo de Salomão'.(Gustave Le Bon, 1895).

ualquer democracia em que as regras eleitorais são respeitadas sujeita a elite hegemônica à possibilidade de ser substituída por lideranças sem vínculos de origem com os integrantes da classe política tradicional. Por isso os processos eleitorais têm sido objeto constante 
de estudos, sendo considerados desde um jogo formal já conhecido até um fenômeno social que ultrapassa os limites da política propriamente dita. Quando um político outsider apresenta uma estratégia de identificação direta com os eleitores, transformando o "povo" de sujeito em objeto de seus discursos, recebe a denominação de "populista". Nas ocorrências pós-ditaduras na América Latina esse político passou a ser chamado de "neopopulista". Quando os neopopulistas são comunicadores sociais é comum encontrar a explicação de que a mudança se deu em virtude da manipulação dos eleitores. Manipulação a partir dos meios massivos de difusão de informações, como por exemplo, o rádio. A questão é: os meios de comunicação de massa nas democracias contemporâneas seriam mesmo os principais responsáveis pelo sucesso eleitoral dos neopopulistas que se candidatam a cargos majoritários ou seriam mais um instrumento de difusão de discursos políticos, como foram os partidos políticos e as organizações classistas no final do século XIX e início do século XX? As transformações nas opiniões do eleitorado não seriam mais bem compreendidas se as suas causas fossem explicadas por fatores sociais ao invés de serem procuradas nos instrumentos de difusão de informações? Se a literatura tem mostrado que a segmentação do voto para cargos legislativos faz com que os meios de comunicação sejam um poderoso instrumento eleitoral nas disputas proporcionais ${ }^{1}$, o mesmo não se pode dizer para as eleições majoritárias - como é o caso das eleições para prefeito municipal.

A volatilidade ideológica e a facilidade para adotar novas estratégias de contato com o eleitor, comuns nos neopopulistas, tidas como deficiências de caráter, podem ser compreendidas como efeitos da sensibilidade que eles têm para perceber as novas demandas da sociedade, diante da necessidade de manutenção dos acordos políticos com parcelas da elite política que ajudaram o candidato a chegar ao poder.

\footnotetext{
' Entre as publicações mais recentes nesse sentido estão os livros Quem me elegeu foi o rádio, de Maurício F. Silva (2000) e Rádio e Política: do microfone ao palanque - os radialistas políticos em Fortaleza (1982-1996), de Márcial Vidal Nunes (2000). Ambos tratam da relação entre rádio e representação política em disputas para legislativos estaduais e não para cargos majoritários.
} 
No cuc diz respeito à forma de governar, há algumas similaridades. () populistals manipulam as massas tanto quanto os não-populistas c ambos governam representando elites políticas distintas da massa. A diferença é que os primeiros conseguem manter uma afinidade maior e mais constante com as predisposições do conjunto dos representados do que os últimos. Quando não, os neopopulistas perdem a capacidade de representação e têm desempenhos eleitorais negativos, mesmo que continuem sendo radialistas, como veremos a seguir.

\section{Populismo e política}

De maneira geral, o populismo é definido como a fórmula política cuja principal fonte de inspiração é o povo. O "povo" no populismo difere do "povo" na democracia, pois, enquanto nesse caso "povo" é o sujeito da ação política (seja diretamente ou através de representantes), no populismo "povo" é o objeto a partir do qual agem as lideranças carismáticas. Quanto ao populismo relacionado a processos eleitorais, Ludovico Incisa (1998, p.981), o define como um movimento em que "um líder carismático recebe o apoio direto de uma massa de eleitores, denominada 'povo'." Portanto, "povo" é aqui considerado como conjunto de indivíduos com interesses próximos. As origens sociais desse fenômeno estão na supressão dos interesses de classe entre os apoiadores do discurso populista ${ }^{2}$. Isso se dá, geralmente, quando uma crise de abrangência social, política e econômica atinge, em maior ou menor grau, a totalidade do grupo social. É uma espécie de alternativa comum acima dos interesses de classe ou outros constrangimentos sociais que possam existir na sociedade. Fenômenos históricos mostram que essa disposição social em favor do populismo é transitória. Basta que a crise termine ou seja reduzida para que as clivagens sociais voltem a prevalecer.

Para Torcuato Di Tella $(1983, \text { p. } 341)^{3}$, as fontes da força populista

${ }^{2}$ Essa supressão dos interesses de classe é pressuposto básico das sociedades de massa.

${ }^{3}$ Outro autor, Alan Angell (1973, p.90), define populismo da seguinte maneira: "o populismo deve ser encarado como um movimento político com forte apoio popular, com a participação de setores não operários que exercem importante influência no partido [ou outros meios de difusão discursiva] e defenden uma ideologia anti-status quo". 
são: “(I) uma elite situada no nível médio ou médio-superior de estratificação, impregnada de motivação anti-status quo; (II) uma massa mobilizada, constituída como resultado da 'revolução de expectativas'; (III) uma ideologia ou um estado emocional generalizado que auxilie a comunicação entre líderes e seguidores e crie entusiasmo coletivo".

O núcleo comum do populismo em suas mais variadas formas de apresentação está na existência dos elementos "povo", "liderança carismática" e "crise de hegemonia". Sendo assim, a unidade do populismo não reside na unidade de conteúdo dos diversos movimentos chamados de populistas.

Mesmo que não exista um cenário de transformação das estruturas sociais, o fator crise é fundamental para a compreensão do neopopulismo - uma atualização do conceito de populismo. Não se trata mais de uma crise de representatividade de antigas oligarquias, mas de uma crise de capacidade de representação sofrida pelas elites em razão do não cumprimento de muitas das promessas da democracia. Em especial, a promessa do atendimento às demandas populares emergenciais através da maior possibilidade de participação e interferência na tomada de decisões públicas. Sem contar as históricas deficiências no atendimento às necessidades individuais básicas, que têm capacidade de mobilização maior que as questões abstratas relacionadas à democracia.

O neopopulismo é legitimado pela descrença que atinge as massas. Ele se beneficia da "fadiga cívica" frente ao Estado, aos partidos políticos e às lideranças tradicionais, e acaba beneficiando as lideranças marginais que defendem soluções inovadoras definindo-se como contrárias ao sistema vigente. É uma forma que as massas encontram para demonstrar insatisfação com a democracia de partidos, que vem sendo instalada na maioria dos países da América Latina, desde os anos 80s.

Há três diferenças básicas entre os fenômenos neopopulistas e as ocorrências populistas clássicas nos países latino-americanos:

1. Enquanto mobilização política, o neopopulismo se apóia em uma reivindicação da massa popular frente a uma classe política que encontrou grandes dificuldades para a institucionalização do regime democrático. 
2. Promoção da antipolítica. A decadência dos partidos, que encontramos na origem de mudanças significativas nos respectivos sistemas de partidos e a crise de confiança na classe política teriam sido determinantes para o novo protagonismo dos políticos marginais do período recente.

3. O surgimento de uma cultura política neopopulista. $\mathrm{O}$ neopopulismo recorre a todo conjunto de idéias, atitudes e valores dos cidadãos desenganados pela promessa democrática e, ao mesmo tempo, propensos às soluções autoritárias. (JIMENEZ. 1997, p.99)

Fica evidente que o histórico distanciamento entre as elites políticas latino-americanas (e brasileiras por certo) das massas transformadas em eleitores nos regimes democráticos é um dos elementos fundamentais para o surgimento e sucesso do neopopulismo em todas as esferas públicas. Mas apenas isso não é suficiente para explicar o desenvolvimento do fenômeno. Mesmo porque o neopopulismo surge como consequiência do descontentamento das massas eleitorais - não se deve esquecer que ele acontece em sociedades democráticas ou em processo de redemocratização, nas quais as massas exercem seus direitos e deveres eleitorais periodicamente.

Uma histórica tendência autoritária entre as massas latinoamericanas, ou uma falta de cultura política plenamente democrática, é o que tem favorecido o ressurgimento das lideranças personalistas. Essa questão precisa ser melhor discutida em razão de seu caráter paradoxal. Por um lado, é incontestável a tendência antidemocrática das massas ao delegar a uma liderança de traços populistas a tomada de decisões políticas em seu nome. Votando em um neopopulista, o eleitor estará afastando a possibilidade de participação política através das instituições formais existentes, pois vai favorecer a liderança personalista à frente do Estado na figura do grande líder. É verdade que isso se dá, em grande parte, pelo desencanto das massas em relação às instituições de representação após processos de desgaste da democracia de partidos que não conseguem atender parte das demandas populares mais primárias. E o não-atendimento dessas demandas se dá pela distância que existe entre a elite política e as classes populares. Esse fenômeno pode ser percebido em toda a América Latina redemocratizada e não apenas no Brasil. 
Por outro lado, há também um traço democratizante no que diz respeito às elites políticas no neopopulismo - aqui está o paradoxo. As elites políticas perdem sensibilidade social, em grande parte, devido aos baixos índices de renovação interna. Na América Latina elas se "fecham" em oligarquias nas cúpulas partidárias que, em última análise, definem aqueles que podem ser candidatos e os que terão mais chances de serem eleitos. Não há um processo continuado de ascensão de novas lideranças para as estruturas partidárias - o que sem dúvida colabora para a perda de legitimidade da democracia de partidos. Com o surgimento de uma liderança "marginal" ao sistema partidário tradicional, essa renovação acontece independente da vontade da elite política. Junto com o neopopulista surge uma classe política renovada, ou "oxigenada", que divide espaço com as velhas lideranças de dirigentes partidários. Não chega a existir uma total substituição dos integrantes da elite, mas a renovação que fatalmente acontecerá é o que permite ao neopopulismo também possuir um caráter democratizante.

\section{Eleições e o rádio}

Um dos principais aspectos no debate sobre o neopopulismo está na discussão a respeito da existência ou não de uma capacidade de ação racional nas massas que sustentam esses movimentos. Até que ponto a adesão ao discurso da mudança é estimulada pela crise das elites hegemônicas, onde começa a capacidade manipuladora das massas pelas lideranças carismáticas ou o comportamento eleitoral baseado puramente em emoções? Essas questões são relevantes aqui por se tratar de um estudo de eleições de radialistas, portanto, de comunicadores profissionais que se tornam políticos. De maneira geral, há uma tendência à minimização da importância do elemento "crise de hegemonia" e uma sobrevalorização da influência da capacidade de convencimento, quase sempre pela emocionalidade, das novas lideranças através dos meios de comunicação. Isso se explica pelo fato dos outsiders utilizarem normalmente a mídia para difundir o discurso da mudança. Os fenômenos neopopulistas se dão em um cenário de descrédito do sistema de representação formal, onde as máquinas partidá- 
rias e corporativas têm função limitada como instrumento de difusão de discursos. Para Maria Lucia Victor Barbosa (1988, p.45), "colocar-se ao lado dos oprimidos é uma tática usada pelas direitas e esquerdas de todas as nuances, levando vantagem os que melhor souberem fazer o papel de 'médium do psiquismo' coletivo."

É necessário distinguir a importância dos meios de comunicação para o fornecimento de informações da influência que a mídia possa ter diretamente no comportamento social - inclusive político. Esses comportamentos são influenciados pela família, religião, escola, trabalho e por um infindável número de outras instituições. Em todas elas é possível encontrar a presença da mídia; por isso torna-se tarefa impossível medir a participação isolada de cada um na conformação dos atores sociais. Para a socióloga Maria Lucia Victor Barbosa (1988, p.88), "meios de comunicação, meios de controle, meios do poder em si nada valem. $\mathrm{O}$ ator político tem que representar um show muito bem ensaiado".

Bernard Manin (1995, p.25-26), atesta as mudanças nas relações políticas contemporâneas no que ele chama de democracia de público e apresenta duas causas para a nova realidade política:

[...] Em primeiro lugar, os canais de comunicação política afetam a natureza da relação de representação: os candidatos se comunicam diretamente com seus eleitores através do rádio e da televisão, dispensando a mediação de uma rede de relações partidárias. [...] $\mathrm{O}$ que estamos assistindo hoje em dia não é a um abandono dos princípios do governo representativo, mas a uma mudança do tipo de elite selecionada: uma nova elite está tomando o lugar dos ativistas e líderes de partido. A democracia do público é o reinado do 'comunicador'. O segundo fator determinante da situação atual são as novas condições em que os eleitos exercem o poder. Reagindo a essas mudanças, os candidatos e os partidos dão ênfase à individualidade dos políticos em detrimento das plataformas políticas.

A espetacularização é o fato novo da política mediatizada e não está presente apenas nas ocorrências neopopulistas. A política moderna também é caracterizada pelo fato da mídia comercial se sobrepor aos veículos de comunicação ideologicamente dirigidos. Os partidos políticos não têm condições de manter jornais ou programas de veiculação nacional. Para serem comercialmente viáveis, os meios de comunicação preci- 
sam demonstrar independência ideológica. Com isso, os consumidores dos discursos têm acesso a mensagens padronizadas e pretensamente neutras. Os políticos disputam as preferências eleitorais em um cenário onde os discursos que mais se aproximarem das expectativas dos eleitores têm maiores chancẹs de sucesso. Como essas expectativas estão em permanente mutação, devido às transformações de conjuntura social e volatilidade dos eleitores, as tendências de preferências das massas deixam de ser constantes. A consequiência imediata disso é que os resultados eleitorais passam a ser cada vez menos previsíveis. "De um lado, toda eleição visa necessariamente distinguir os que apóiam um candidato dos que são contrários a ele. Por outro, as pessoas se mobilizam e se unem mais quando têm adversários e percebem existir diferenças entre elas e os demais. Os candidatos precisam não só identificar a si próprios, mas também definir seus adversários" (MANIN, 1995, p.27).

É durante as campanhas que os eleitores definem a inclinação em favor ou contra as mensagens difundidas naquele momento - isso não significa que as informações recebidas e a experiência cotidiana anterior ao processo eleitoral sejam dispensáveis no processo de escolha dos eleitores. O voto, que é a vontade eleitoral sedimentada, é relativo à soma das experiências vividas com a interpretação das mensagens políticas durante a campanha eleitoral. Ele é definido a partir de uma reação do eleitor aos diferentes discursos difundidos pelos candidatos e seus apoiadores. Para Manin (1995, p.28):

Os políticos têm uma autonomia apenas parcial ou relativa na seleção dos assuntos que dividem o eleitorado; eles não podem inventar, com total liberdade, os princípios da clivagem que irão compor [...]. O candidato toma a iniciativa de propor uma linha divisória durante a campanha, ou, com menos riscos, a partir das pesquisas de opinião. O público, a seguir, responde à divisão proposta e, por fim, o político corrige ou mantém a proposta inicial, dependendo da reação do público.

A formação da imagem de determinado candidato a cargo público se dá em grande parte durante a campanha eleitoral. Mas o histórico dos políticos também é levado em consideração pelos eleitores. Dessa forma, para ser bem sucedido, todo candidato precisa saber adaptar 
seu discurso às demandas sociais mais agudas; aquelas que sensibilizam um número maior de eleitores, sem parecer artificial. Os Meios de Comunicação de Massa servem para ampliar a visibilidade de determinado ator e seu discurso. Mas se a fala dele não estiver de acordo com as demandas sociais, suas chances de sucesso eleitoral serão reduzidas. Nas palavras de Barbosa (1988, p.89), "nenhum supermercado eleitoral, nem meios de comunicação, conseguem a identificação consumada na boca da urna. Se tudo isso ajuda, fica por conta de um indefinível 'algo mais' que possui o feiticeiro das massas [...] a capacidade de converter momentaneamente a descrença em crença”.

Demandas sociais não atendidas, que são as geradoras das crises sociais, não têm ligação direta com o surgimento de um radialista/ político no cenário eleitoral local. O que os comunicadores outsiders fazem é ressaltar os problemas já enfrentados pela população em seus programas radiofônicos, daí a presença da violência, do abandono social e dos problemas vividos pelos "pobres" 4 . A perda de exemplaridade da elite dirigente tradicional é outro fator que antecede a presença do outsider. Os dirigentes políticos deixam de ser capazes de representar a sociedade quando não conseguem identificar as demandas sociais. O que o radialista faz é publicizar as limitações da elite dirigente e propor sua substituição a partir de fatos sociais ${ }^{5}$. Sendo assim, é possível considerar que a existência de predisposições sociais, tais como crise social e surgimento de uma liderança carismática, aliadas à capacidade dos meios de comunicação de massa para difundir mensagens mudancista sejam indispensáveis para o sucesso eleitoral de outsiders em política local.

A "manipulação das vontades dos eleitores" não está na origem dos neopopulistas/radialistas. As condições sociais básicas para

\footnotetext{
+ Maurício Silva lembra que, diferente dos contatos diretos em que o candidato tem limitações, o contato através da mídia possibilita a criação de estratégias para que a interpretação dele se aproxime da opinião pública, ou seja, o político aparece de acordo com os anseios do eleitorado. (SILVA, 2000, p.31).

${ }^{5}$ Quando em seus programas os radialistas/políticos apresentam casos de pessoas que não foram atendidas pelo sistema público de saúde ou que sofreram algum tipo de dano causado pelas más condições dos serviços de responsabilidade do município, eles estão tornando uma experiência pessoal em fato social; o que é diferente de criar demandas sociais para manipular as vontades dos eleitores.
} 
o sucesso eleitoral desse tipo de liderança depende menos da capacidade doutrinadora do comunicador e mais das condições externas a ele. É preciso ter em mente que a adoção de uma postura oposicionista pela massa não se dá simplesmente por reação automática a estímulos psicológicos ou ao simbolismo radiofônico. Sobre isso, Sandor Halebsky (1978, p.155) sugere o seguinte:

Devemos procurar um melhor entendimento do mundo subjetivo do dissidente político e da construção interpretativa do significado em termos dos quais ele explica suas circunstâncias ambientais. Isso deve incluir a compreensão da experiência consciente e a interpretação, pelo indivíduo, das características sistêmicas externas, bem como das diversas condições presentes no ambiente imediato. [...] A política radical (aqui considerada como apoio à liderança neopopulista) não é, em geral, uma explosão expressiva, mesmo em frustração, uma busca de comunidade, ou um meio de evidenciar hostilidades ou peculiaridades sociais. É, isso $\operatorname{sim}$, a seleção de uma entre várias alternativas, à luz das necessidades individuais, que envolve uma interação interpretativa com o ambiente e um processo de educação ou aprendizado político, no tempo, pouco diferente em princípio da maioria dos tipos de formação de atitude.

O comportamento político neopopulista depende de uma liderança carismática que tenha competência para instrumentalizar os meios de comunicação de massa, mas sua origem social é explicada pela crise de hegemonia dos governantes que, por sua vez, pode ter várias causas: crise social, política ou econômica, considerando que é praticamente impossível estabelecer os limites de cada esfera.

\section{Neopopulismo em Ponta Grossa nos anos 90 s}

Entre os anos 80 e 90 houve na política local de Ponta Grossa a consolidação de um perfil único de representantes entre as principais lideranças locais que chegaram à prefeitura. $\mathrm{O}$ município passou por uma crise econômica que começou em meados dos anos 70 e seguiu até meados dos anos 90 . Nesse período surgiu no cenário 
político local um outsider carismático com as características de um neopopulista, o radialista Jocelito Canto, que conseguiu ser eleito prefeito em 1996.

O radialista Jocelito Canto chegou a Ponta Grossa em 1991 à procura de emprego. Bateu às portas de todas as rádios da cidade sem sucesso. Então alugou uma caixa amplificadora de som e um microfone para fazer apresentações populares na praça central da cidade. "Abria" o microfone para a população apresentar suas queixas. Conseguiu levar alguns políticos para debater com o povo em praça pública e seu programa ganhou repercussão. Depois disso voltou a procurar as rádios.

A dificuldade em conseguir emprego nas rádios devia-se ao fato de Canto fazer programas popularescos e o perfil dos proprietários das cinco rádios AM de Ponta Grossa ser conservador. Na época eram cinco rádios AM. A rádio Santana pertencia à Cúria. A Rádio Clube Ponta-grossense pertencia na época ao ex-deputado Jovani Masini, político tradicional da cidade que foi o vice-prefeito de Paulo Cunha Nascimento de 1992 a 1996. A Rádio Central do Paraná pertencia ao empresário Irajá Vargas de Oliveira, candidato a deputado federal em 1994 e candidato a vice-prefeito de Plauto Miró Guimarães Filho em 1996. A Rádio Nacional Sul estava arrendada para a família Andrade, de Curitiba, que tinha interesses em eleger um deputado da família. A única rádio AM local que não tinha ligações diretas com políticos era a Difusora - com exceção da rádio Santana, que pertencia à cúria.

Na rádio Difusora, Canto foi informado que não teria espaço para usar o estúdio, mas se quisesse poderia fazer o seu programa matinal da garagem do prédio. Foi assim que surgiu a Garagem da Esperança, programa popular onde mediante o qual Canto intermedeia doações de ouvintes para pessoas carentes. Em 1994 ele se candidatou a deputado estadual pelo nanico PSC (Partido Social Cristão). Sua pretensão era ganhar experiência eleitoral e ser reconhecido como político para facilitar uma possível eleição para vereador em 1996. Conseguiu ser eleito como único deputado estadual de uma coligação de partidos nanicos daquele ano para a Assembléia Legislativa do Paraná. Ele fez mais de 19 mil votos só 
em Ponta Grossa. Sua votação total atingiu em 20,5 mil votos ${ }^{6}$. Em 1994 os candidatos a deputado tradicionalmente eleitos por Ponta Grossa foram Plauto Miró Guimarães (PFL) e Luiz Carlos Zuk (PDT), ambos fizeram cerca de 10 mil votos cada um no município, além de Péricles de Holleben Melo (PT), com cinco mil votos dos pontagrossenses.

Canto não pertencia a famílias tradicionais de Ponta Grossa. Natural do Rio Grande do Sul, não fazia parte da elite ęconômica local e jamais foi empresário. O perfil oposto aos prefeitos anteriores e a sensibilidade para reconhecimento das novas demandas populares fizeram de Canto a principal opção oposicionista no município em 1996, substituindo os opositores já conhecidos da elite política hegemônica local: Djalma de Almeida César e Luiz Carlos Zuk. Em 1996, depois de dois anos como deputado estadual e com a Garagem da Esperança melhor estruturada, Jocelito Canto se transformou em candidato natural da oposição à prefeitura local. Em 2000, quando completava seu primeiro mandato de prefeito sem ter deixado de fazer o programa Garagem da Esperança, Jocelito Canto não conseguiu repetir o bom desempenho eleitoral de 1996. Ele foi derrotado por Péricles de Holleben Melo (PT). Canto não conseguiu cumprir as "promessas" feitas aos eleitores e perdeu a exemplaridade como líder, apesar de seu carisma. Isso resultou na sua substituição por um político de perfil oposto ao seu e diferente do perfil tradicional das lideranças locais. Mas antes disso, quem primeiro teve a capacidade de representação popular reduzida, abrindo espaço para a opção neopopulista, foram as elites com perfil tradicional. Se em Londrina esse perfil baseava-se na posição social dos representantes, em Ponta Grossa ele ainda é mais fácil de ser identificado, pois envolve laços familiares entre os integrantes da elite hegemônica local.

' Além de Ponta Grossa, Canto foi bem votado no município de Ubiratã, sudoeste do Estado, onde morara alguns anos antes. Em Ubiratã ele trabalhou em uma rádio administrada pelo grupo político dominante local. Chegou a ser nomeado para o cargo de Secretário Municipal de Esportes antes de se desentender com o prefeito e deixar a cidade. 


\section{Elite Política Local Não-Populista ${ }^{7}$}

O primeiro prefeito não-populista das décadas de 80 e 90 em Ponta Grossa foi Otto Santos Cunha, eleito em 15 de novembro de 1982 pelo $\mathrm{PMDB}$. Aquelas foram as últimas eleições municipais em que a legislação permitiu a formação das sublegendas, quando mais de um candidato concorria pela mesma sigla. O PMDB indicou dois candidatos: os empresários Otto Santos Cunha e José Gomes do Amaral. Os principais opositores eram do PDS: os empresários Cyro Martins, Plauto Miró Guimarães (pai do atual deputado estadual e candidato a prefeito em 1996, Plauto Miró Guimarães Filho), além de Cesar Fernando Pilati. Pelo PTB se candidataram Brasil Ribas Neto e Antonio Maire, também empresários. O PT, que disputava suas primeiras eleições nacionais, lançou apenas um candidato, o professor universitário Péricles de Holleben Mello. A chegada de Otto Cunha ${ }^{8}$ à prefeitura em 1982 marca o início do período de governos não-populistas (Anexo 1).

O Secretário de Finanças do governo Otto Cunha foi seu primo, Paulo Cunha Nascimento, que veio a ser o último prefeito não-populista do período. Otto Cunha conseguiu se eleger deputado federal em 1990 , dois anos depois de terminar o mandato de prefeito. Não foi reeleito em 1994. Participou das eleições municipais de 1996 como conselheiro da campanha de Plauto Miró Guimarães Filho. Em 1998 não viabilizou politicamente sua candidatura a deputado federal.

O segundo prefeito de Ponta Grossa no período de não-populistas foi o empresário Pedro Wosgrau Filho, eleito em 15 de novembro de 1988 (Anexo 2). Nessa eleição não existiam mais as sublegendas. Pedro Wosgrau Filho foi candidato pelo nanico PDC (Partido Democrata Cristão). Engenheiro civil formado pela Universidade Federal do Paraná (UFPR), come-

\footnotetext{
${ }^{7} \mathrm{O}$ conceito "não-populista" é aplicado aqui como oposição à postura de um político populista. Enquanto os populistas agem de maneira a responder rapidamente às demandas populares, os não-populistas priorizam a responsabilidade em seus atos. A retórica do governante em ambos os casos também difere. Os populistas dizem governar com o povo enquanto os não populistas afirmam governar para o povo.

${ }^{8}$ Otto Santos Cunha faz parte de uma das famílias mais tradicionais de Ponta Grossa. Os Cunha chegaram ao município no século passado para explorar a pecuária de corte e a atividade madeireira em extensas áreas rurais na região. Otto Cunha é pecuarista por herança familiar. Integra a elite econômica do município.
} 
çou sua vida profissional em uma construtora da família Wosgrau em Ponta Grossa. É descendente de família tradicional da cidade. Atua profissionalmente na área de incorporação de imóveis. Tem propriedades rurais e uma madeireira. Também faz parte da elite econômica da cidade. Foi o indicado de Otto Cunha para dar continuidade à administração municipal e teve como vice-prefeito Paulo Cunha Nascimento, que acumulou a função de vice-prefeito com a de Secretário de Finanças do Município na administração de Wosgrau ${ }^{9}$.

O terceiro prefeito do período, Paulo Cunha Nascimento, eleito no dia 3 de outubro de 1992, governou a cidade de 1993 a 1996 (Anexo 3 ). Sua eleição também foi pelo PDC. Tinha sido Secretário Municipal de Finanças do primeiro governo não-populista e vice-prefeito no segundo. Pertencente a uma família tradicional da cidade, Paulo Cunha administrava uma beneficiadora de sementes e propriedades agrícolas da família. Pela primeira vez na terceira colocação apareceu o PT, com Padre Roque Zimermann como candidato. Em quatro lugar, o dono de um jornal local, Adail Inglês, candidato do PTB. Paulo Cunha não tinha experiência em disputas eleitorais como candidato antes de concorrer a vice-prefeito em 1988. Até 1983, quando fora nomeado Secretário Municipal de Finanças, sua vida profissional era nas propriedades rurais da família e na empresa Joná Sementes, beneficiadora de sementes agrícolas fundada pelo pai, João Nascimento. Em terceiro lugar, naquelas eleições, ficou o candidato do PT, Padre Roque Zimermann. Paulo Cunha não fez uma administração popular. Teve altos índices de rejeição no final do mandato ${ }^{10}$. Tanto que o candidato da continuidade, Plauto Miró Guimarães Filho, não aceitou seu apoio oficial. O quadro abaixo mostra os desempenhos eleitorais dos candidatos situacionistas em Ponta Grossa entre 1982 e 1996 e o principal representante da oposição em cada disputa.

\footnotetext{
"Naquela campanha eleitoral, os principais adversários da "situação" foram o exprefeito e empreśríro rural Luiz Carlos Zuk (PDT), terceiro colocado; e o então deputado estadual Djalma de Almeida Cesar (PMDB), militante político na cidade desde o início dos anos 70s, foi o segundo colocado. A opção dos eleitores foi clara pela continuidade do grupo hegemônico no poder naquela ocasião. Em quarto lugar naquelas eleições ficou o candidato do PT, Silvio Fernandes da Silva.

${ }^{10}$ Fonte: pesquisas de desempenho administrativo realizadas pelo Jornal da Manhã, de Ponta Grossa, durante o ano de 1995.
} 
Quadro I

Desempenho da elite política hegemônica e oposição eleitoral em Ponta Grossa entre 1982 e 1996 (\% votos válidos)

\begin{tabular}{l|l|l|l|l|l|l|l|} 
1982* $^{*}$ & $\%$ & $\mathbf{1 9 8 8}$ & $\%$ & $\mathbf{1 9 9 2}$ & $\%$ & $\mathbf{1 9 9 6}$ & $\%$ \\
Otto Cunha & 62,4 & Pedro Wosgrau & 46,7 & Paulo Cunha & 41,9 & Plauto Miró & 24,04 \\
Cyro Martins & 34,5 & Djalma Cesar & 27,5 & Djalma Cesar & 33,3 & Jocelito Canto & 42,0
\end{tabular}

*Soma dos votos do principal candidato do partido e dos outros da sublegenda

Fonte: TRE do Paraná

A aplicação do índice de avanço partidário para os votos brancos e nulos em Ponta Grossa entre 1982 e 1996, assim como no caso de Londrina, mostra que havia um contínuo desgaste das lideranças políticas de perfil tradicional na cidade durante o período não-populista.

\section{Tabala 1}

\section{Índice de avanço de votos brancos e nulos em Ponta Grossa (1988 a 1996)}

\begin{tabular}{l|r} 
Eleição municipal de 1988 & 84.740 \\
Total votos: & 6.785 \\
Total votos brancos e nulos: & 2,78 \\
Índice de avanço de votos brancos e nulos & \\
Eleição municipal de 1992 & 123.646 \\
Total votos & 7.245 \\
Total votos brancos e nulos & 1,72 \\
Índice de avanço de votos brancos e nulos & \\
Eleição municipal de 1996 & 134.305 \\
Total votos & 5.015 \\
Total votos brancos e nulos & 0,20 \\
Indice de avanço de votos brancos e nulos &
\end{tabular}

5 Neste ponto, queremos chamar a atenção do leitor para um fato que nos parece um tanto quanto sugestivo: Nelson Jobim, autor de um projeto de lei que regulamentava e restringia o uso de medidas provisórias pelo presidente da República (quando deputado, em 1991), fora "promovido", em janeiro de 1995 , à posição de ministro da Justiça do governo Fernando Hemrique Cardoso. 
O índice de avanço dos votos brancos e nulos de Ponta Grossa no período anterior à eleição do radialista/neopopulista manteve-se positivo. Evidente que uma parcela desses votos brancos e nulos deve-se não ao descontentamento do eleitor, mas a erros no momento da votação ou interpretação dos escrutinadores (na época a votação e apuração dos votos era manual). O que importa aqui não são os números absolutos de votos brancos e nulos, mas o seu crescimento contínuo entre duas eleições. Essa tendência serve como indicador de descontentamento do eleitor local e aconteceu tanto em Londrina como em Ponta Grossa.

Com a não-eleição de Plauto Miró Guimarães Filho e a chegada à prefeitura do radialista Jocelito Canto em 1996, termina o período de governos não-populistas em Ponta Grossa (Anexo 4). Saem de cena os prefeitos empresários ou proprietários rurais, nascidos em Ponta Grossa e descendentes de famílias tradicionais da cidade, encerrando o período de governos de continuidade, com o mesmo perfil administrativo.

\section{Decadência econômica de Ponta Grossa nas décadas de 80 e 90}

Nos 13 anos de governos não-populistas (1983 a 1996), Ponta Grossa viveu uma estagnação econômica. Depois de um vertiginoso crescimento industrial nos anos 70 , com a instalação dos complexos moageiros de soja no município, a economia parou de crescer durante os governos não-populistas. O PIB percapita de Ponta Grossa se transformou em um dos menores entre os municípios médios do Estado e as perspectivas profissionais se definharam entre os anos 80 e 90 .

Mesmo sendo um município mais antigo, em 1996 Ponta Grossa (172 anos à época) tinha praticamente a mesma população que Maringá (60 anos). Eram 266.390 habitantes no primeiro e 286.068 habitantes no segundo município (IBGE, 2000). Comparando alguns indicadores econômicos dos dois municípios percebe-se o fraco desempenho da economia ponta-grossense em meados dos anos 80 s.

Apesar da indústria em Ponta Grossa ter uma participação maior na economia local que em Maringá, a renda percapita do ponta-grossense, em meados dos anos 90 s, estava cerca de $20 \%$ abaixo da renda percapita 
(o) maringaacnse. () númrero dè estabelecimentos industriais de Maringá cra o dobro do Ponta Grossa no ano da eleição do neopopulista, embora a participaçào do setor na renda total fosse maior em Ponta Grossa. Maringá também tinha um setor de serviços mais desenvolvido que Ponta Grossa. O setor agropecuário de Ponta Grossa tem três vezes mais participação na renda municipal que o de Maringá. O setor terciário (de serviços), que apresenta a maior capacidade de distribuição de riqueza e exige profissionais mais especializados, em Maringá estava mais desenvolvido que o setor terciário de Ponta Grossa. Esse é outro indicativo da concentração de renda e da lentidão no desenvolvimento econômico de Ponta Grossa. Por último, a participação da economia agropecuária no total da riqueza gerada no município é três vezes mais importante que em Maringá. Aqui, faz-se uma distinção rápida, mas importante. Enquanto em Maringá a economia agropecuária é caracterizada principalmente por pequenas e médias propriedades rurais, em Ponta Grossa a predominância é de grandes propriedades. Em Maringá, as características do solo garantem um tipo de exploração agrícola mais intensiva. Em Ponta Grossa há grandes extensões de áreas rurais com pouca fertilidade, que só podem ser exploradas pela pecuária extensiva. É essa a razão por que a predominância de grandes propriedades rurais, a concentração de renda no campo e a pobreza da população rural em Ponta Grossa são maiores que em Maringá.

\section{Tabata 2}

\section{Indicadores econômicos comparativos entre Ponta Grossa e Maringá em 1996}

Indicadores econômicos
Produto Interno Bruto (US\$)
Crescimento da Pop. Urbana (\%)
Crescimento da População Rural (\%)
Número de indústrias
Número de comércio varejista
Número de comércio atacadista
PIB agropecuário (\%)
PIB industrial $(\%)$
PIB serviços (\%)
Fonte: IPARDES (1996)

\begin{tabular}{r|r} 
Ponta Grossa & Maringá \\
$764.580 .064,88$ & $1.042 .827 .354,58$ \\
1,96 & 2,20 \\
$-0,51$ & 2,38 \\
610 & 1.240 \\
3.354 & 4.212 \\
205 & 677 \\
3 & 1 \\
30 & 22 \\
67 & 77
\end{tabular}


Considerando que o menor número de indústrias e a maior participação delas na economia demonstra que o setor industrial de Ponta Grossa era concentrado em um pequeno número de grandes fábricas, percebe-se que também existia uma tendência à concentração de renda na área urbana deste município. As características da atividade agropecuária local e sua importância no total da economia gerada apontam para uma concentração de renda. O menor PIB percapita de Ponta Grossa mostra uma atividade econômica menos auto-suficiente, com evasão de recursos para outros municípios ou regiões.

Estes fatores geraram uma pressão social crescente por mudanças na atividade econômica local. Os políticos que administraram a cidade no período foram os primeiros a sofrer os efeitos negativos. Os eleitores, que também são os pequenos empresários em busca da expansão do setor de prestação de serviços, ou os trabalhadores assalariados em busca de melhores rendimentos, ou os pequenos industriais que esperam condições favoráveis ao crescimento de suas empresas, fizeram a opção por uma administração municipal com perfil distinto do não-populista em 1996.

A renda percapita anual e os índices de potencial de consumo (IPC) dos principais municípios paranaenses entre 1983 e 1997 também demonstram a estagnação econômica de Ponta Grossa nesses 14 anos. O período em que os prefeitos não-populistas administraram o município de Ponta Grossa coincidiu não apenas com uma estagnação econômica local, mas com uma queda nos indicadores econômicos da cidade em relação a outros municípios do Estado.

Em 1983, quando começou o primeiro governo não-populista de Ponta Grossa, a renda percapita anual do ponta-grossense só perdia para a do curitibano entre os municípios pesquisados, e o índice de potencial de consumo de Ponta Grossa era o segundo maior do interior do Paraná. Em 1997 a renda percapita de Ponta Grossa passou a ser a pior entre os municípios de porte médio do Paraná e encontrava-se abaixo da média estadual. O IPC acompanhou a queda, ficando à frente apenas de Cascavel e Foz do Iguaçu em 1997. As condições econômicas desfavoráveis e a queda da riqueza local formaram o cenário ideal para o discurso populista da mudança política e tiveram efeitos diretos na escolha dos eleitores em 1996. Assim como visto nas explicações para 
as ocorrências populistas clássicas, houve uma massificação da demanda social por melhorias na economia local, pois integrantes de todas as classes vinham sofrendo as conseqüências da crise social, que terminou se transformando em crise do discurso hegemônico a partir do momento em que as elites dirigentes demonstraram não ter condições para solucionar a crise.

As perspectivas de desenvolvimento pessoal e o poder aquisitivo de todas as classes sociais foram-se restringindo gradativamente em Ponta Grossa entre os anos 80 e 90 . Como os governantes estavam distantes das classes populares, as políticas públicas implementadas por eles não atendiam às novas demandas sociais. As pressões para uma ampliação e transformação da elite dominante cresceram até o ponto da substituição desta elite pela liderança neopopulista. Se o grupo político hegemônico tivesse percebido essa tendência a tempo de fazer uma aliança e ampliar a participação de setores sociais no governo, o discurso populista perderia força. O outsider Jocelito Canto não personificou apenas uma "mudança" durante a campanha eleitoral de 1996, mas a mudança em favor do atendimento às demandas sociais reprimidas.

A coincidência histórica entre a estagnação econômica e a permanência de representantes com o mesmo perfil político no poder no mesmo período foram decisivos para o sucesso eleitoral do neopopulismo. Durante os 13 anos de governos não-populistas, a administração municipal de Ponta Grossa tentou ser o mais "responsável" possível. O discurso político predominante era o da elite econômica responsável pela preservação dos bens públicos. Eram governos para o povo, comuns, quando a elite política sente-se mais capacitada para decidir o que é melhor para a sociedade do que a própria sociedade.

Essa postura de afastamento das bases sociais gerou distorções na implementação de política públicas, o que iniciou a crise no discurso hegemônico. As lideranças tradicionais deixaram de ser consideradas a melhor opção eleitoral, gerando o vazio político propício para o crescimento do populismo eleitoral. As políticas públicas "responsáveis" implementadas pelos governos não-populistas foram apresentadas em forma de discurso político nas campanhas eleitorais de 1982 a 1992 e aceitas pela maioria dos eleitores. Para poder 
compreender como a distorção entre discurso e prática abriu espaço ao populismo é preciso considerar como as promessas eleitorais do grupo não-populista se transformaram em política pública, por exemplo.

Uma das constantes promessas de campanha dos governos não-populistas foi fazer investimentos em saúde pública. A demanda da população nessa área era por atendimento público em maior quantidade (número de consultas disponíveis). Nas três administrações que antecederam Canto multiplicou-se o número de postos de saúde da prefeitura, descentralizando o atendimento para os bairros. De Otto Cunha a Paulo Cunha as unidades de saúde em funcionamento nos bairros passaram de dez em 1983 para 62 em 1996, em um município com cerca de 263 mil habitantes no final do período. A estrutura de atendimento cresceu $500 \%$ em pouco mais de uma década ${ }^{11}$ enquanto o crescimento anual médio da população ficou abaixo de $2 \%$, segundo dados do IBGE (2000).

Apesar dos investimentos na construção de novas unidades de saúde, a população continuou sem o atendimento médico público descentralizado que exigia porque as obras não foram acompanhadas pela contratação de novos médicos. No final do governo Paulo Cunha o município tinha 62 postos de saúde e apenas 30 médicos clínicos gerais, pediatras ou ginecologistas para prestar atendimento nestas unidades. Cada uma delas tinha médico, em média, duas vezes por semana e a população dos bairros era obrigada a procurar os serviços do pronto-socorro municipal ou hospitais do centro da cidade.

Político sensível às demandas sociais, Jocelito Canto soube explorar os desvios entre as promessas e as ações práticas dos governos não-populistas. Criticou as filas no pronto-socorro, a falta de médicos nas unidades de saúde dos bairros e a desatenção das administrações municipais com as classes sociais carentes. Em seu programa de rádio, ele apresentava com frequiência casos de pessoas que precisavam do serviço público de saúde e não conseguiam ser atendidas no pronto-socorro. Relatos de crianças que passavam a

1 Para entender a desproporção da decisão política em relação às demandas populares, o município de Curitiba, que na mesma época tinha 1,2 milhão de habitantes, era servido por 95 postos de saúde municipais. 
madrugadat em salas te espera dos hospitais também eram comuns. Durante a campranha eleitoral de 1996, uma das principais promessas de Canto foi a inauguração de quatro postos de saúde, um em cada região da cidade, com atendimento médico 24 horas por dia. Assim, a população não se deslocaria mais para o centro da cidade quando precisasse de atendimento a qualquer hora do dia ${ }^{12}$. Esse exemplo mostra como um governo responsável, mas sem bases populares sólidas, pode se equivocar na implementação de políticas públicas e abrir espaço para o surgimento de uma oposição com força eleitoral suficiente para chegar ao poder.

O programa de rádio Garagem da Esperança serviu como instrumento para identificação do radialista com o discurso populista. O que deu espaço para o crescimento da aceitação deste discurso foi o baixo índice de responsividade das administrações não-populistas. Se a implementação das políticas públicas deste período, e principalmente no último mandato, tivesse considerado as novas demandas da sociedade ${ }^{13}$, seria mais difícil o convencimento do eleitor pelo discurso da mudança, mesmo que ele fosse transmitido via ondas hertzianas. Sucessivos fracassos na implementação de políticas públicas pelos governos não-populistas abriram espaço para que a oposição política populista crescesse.

Governos "responsáveis" não fazem questão de se interrelacionar com diferentes organizações sociais. Por isso estão mais sujeitos ao acúmulo de pequenos déficits na implementação das políticas públicas (HAM; HILL, 1993). Lembrando trabalhos de outros autores, Ham e Hill introduzem ao debate sobre implementação de políticas públicas o conceito de déficit segundo o qual, quando a cooperação entre as organizações envolvidas na implementação das políticas públicas é menor que a perfeita, passa a existir um déficit cumulativo. No caso dos governos não-populistas de Ponta Grossa, esse déficit começou a se acumular quando as políticas implementadas,

\footnotetext{
12 Essa promessa não foi cumprida no início do mandato de Canto, como prometido. O secretário municipal de saúde chegou à conclusão que seria muito caro manter médicos de plantão em quatro unidades de saúde 24 horas para um baixo número de atendimentos durante a madrugada.

${ }^{13}$ Como mais médicos nos bairros da periferia, por exemplo.
} 
fruto das promessas de campanha, deixaram de cumprir o papel desejado pelo conjunto da sociedade.

Associa-se a isso o conceito de sistema Top-Down de implementação das políticas públicas, segundo o qual as ações dos indivíduos ou grupos públicos são dirigidas a objetivos previamente estabelecidos mediante decisões políticas, sem que para tanto seja necessário ouvir as bases sociais - a população que será afetada pelas decisões.

Ao procurar compreender as complexidades do processo de tomada de decisões, autores têm posto em evidência uma variedade de modelos entre os quais o enfoque sistêmico esboçado por David Easton tem recebido considerável proeminência. Easton discute que a atividade política pode ser analisada em termos de um sistema contendo uma série de processos que devem permanecer em equilíbrio a fim de que a atividade sobreviva (HAM; HILL, 1993, p.15).

A chave do enfoque sistêmico é a relação com um sistema biológico em que processos vitais interagem com o meio ambiente para produzir um estado mutável e, em razão disso, instável. Neste modelo simplificado de decisões políticas, um dos processos fundamentais é o das entradas. As demandas são ações de indivíduos ou grupos em busca de resultados que possam lhes favorecer ${ }^{14}$. Os apoios dão o impulso necessário para que as demandas sejam transformadas em atos concretos - votação na Câmara de Vereadores autorizando a contratação de empreiteiras para construir novos postos de saúde ou abertura de concurso público para contratação de médicos. Isso tudo entra na estrutura de tomada de decisões para depois sair em forma de implementação de políticas públicas. Na análise, o autor admite ainda a realimentação do sistema através das influências que as saídas e ações terão nas futuras entradas do sistema.

Em um sistema político democrático, com eleição periódica de tomadores de decisões políticas, a realimentação das entradas é um

\footnotetext{
${ }^{14}$ Como, por exemplo, o atendimento médico gratuito de melhor qualidade para as populações da periferia de Ponta Grossa, prometido em campanha política.
} 
dos pontos fundamentais para a manutenção de um grupo político no centro da tomada de decisões. A responsabilidade por esta realimentação é dos grupos de pressão da sociedade que têm acesso direto à elite política - que toma decisões. Os grupos de pressão estão livres da estrutura burocrática e "disponíveis" para receber as demandas do ambiente e introduzi-las na caixa de tomada de decisões. Se por qualquer motivo essa realimentação for distorcida ou começar a falhar, as decisões e ações da elite política se dissociam das expectativas do conjunto da sociedade. É quando começa a decadência de uma elite política e sua substituição por outro grupo. A falta de conexão entre as ações públicas e as demandas da sociedade foi responsável pela substituição dos governos não-populistas em Ponta Grossa. Esse distanciamento era uma característica natural do grupo político nãopopulista. Mas a sucessão de governos com o mesmo perfil e o acirramento das disputas internas o acentuou a ponto de se tornar estranho ao conjunto da sociedade.

Na prática, o distanciamento da elite política não-populista que governou a prefeitura de Ponta Grossa pode ser percebida nas ações de alguns grupos de pressão institucionalizados. As duas principais instituições que deram sustentação aos governos nãopopulistas no início do período foram a Sociedade Rural dos Campos Gerais (SRCG) e a Associação Comercial e Industrial de Ponta Grossa (ACIPG). Outras instituições também faziam a intermediação entre a elite política eleita e os interesses da sociedade, mas estas duas, por serem as maiores, tinham direito a indicar secretários municipais e a participar de decisões importantes do poder público. Por tradição dos prefeitos daquele período, o Secretário Municipal de Indústria e Comércio era indicado pela ACIPG e o Secretário Municipal de Agricultura era indicado pela SRCG. Antes da existência de secretarias específicas, as associações classistas indicavam os diretores de departamentos ligados aos setores de indústria, de comércio e de agricultura. Boa parte das demandas dos grupos sociais representados por estas instituições chegavam ao centro de tomada de decisões públicas por intermédio de "seus" secretários. A manutenção dos secretários "classistas" garantia as "entradas" no sistema político com poucas distorções e que a implementação de políticas públicas 
atenderia as demandas desses grupos. A sucessão de governos fez com que a elite política não-populista se sentisse cada vez mais autosuficiente e os selecionados para os postos de tomada de decisões passaram a desconsiderar as pressões externas.

O caso mais aparente é o da SRCG no último mandato do período não-populista. A direção desta entidade, que representa a classe dos pecuaristas locais, apoiou a eleição dos três prefeitos não-populistas. Afinal de contas, todos eles tinham ligações diretas ou indiretas com o setor agropecuário. Durante o primeiro mandato, a SRCG dividiu o centro das decisões políticas com a ACIPG. Ambas conseguiam interferir na tomada das principais decisões políticas e inter-relacionavam a elite política com a sociedade, pois juntas representam a maior parte da população economicamente ativa do município. No segundo governo, como Wosgrau Filho era principalmente um empresário urbano (construção civil e incorporação de imóveis), a Associação Comercial ganhou espaço como grupo de pressão da classe política. O centro do poder foi-se distanciando gradativamente da Sociedade Rural. Isso pode ser percebido na composição dos conselhos municipais. A partir dos anos $90 \mathrm{~s}$, os estatutos destas entidades normalmente prevêem a indicação de um representante da Associação Comercial e raramente um da Sociedade Rural.

É no terceiro governo do período que o afunilamento da elite política fica mais nítido. A Sociedade Rural passou de grupo de pressão distante para quase opositora da administração. O prefeito Paulo Cunha Nascimento manteve durante todo seu mandato o Secretário de Agricultura e Pecuária, Cristiano Justus Neto. Como não era indicação da Sociedade Rural, o Secretário não priorizava o atendimento às demandas do grupo de pressão. Achava que a Secretaria deveria dar apoio à pequena e média propriedade, por ser menos organizada e com menor representação no poder público. As discordâncias cresceram a tal ponto que o Secretário, sendo pecuarista e proprietário de uma pista de remates, marcava os leilões gerais em sua propriedade para os mesmos finais de semana em que ocorreriam os eventos da Sociedade Rural. Como o prefeito manteve o Secretário no cargo, a conclui-se é que a opção de Paulo Cunha foi pelo afastamento do grupo de pressão em favor da manutenção do 
Secretário. Só no final de seu mandato, em junho de 1996, o prefeito anunciou à direção da Sociedade Rural que faria um empréstimo municipal para a construção do Parque Agropecuário de Ponta Grossa. Obra que não chegou a concluir em seu mandato ${ }^{15}$.

As dissidências na classe política foram fortalecendo a oposição, que se aproveitou da ascensão de uma nova liderança popular, sem vínculos com a classe dirigente, e, portanto, identificada como legítima representante do povo, para voltar ao poder. A campanha eleitoral de 1996 mostra que Jocelito Canto não entrou na disputa apenas com a ajuda da massa. Ele foi a "cabeça" de um corpo de dissidentes da classe política que se formou durante os 13 anos de seleção interna da elite política não-populista de Ponta Grossa. Canto foi a opção que os agropecuaristas encontraram para retornar ao centro do poder. Tanto que os Secretários de Agricultura do governo de Canto foram indicados pela SRCG. E a nomeação do Secretário de Indústria e Comércio "apenas" recebeu o apoio da ACIPG. A candidatura de Jocelito Canto à prefeitura em 1996 também é o resultado de um realinhamento da classe política local. Nesse sentido, há uma diferença entre o neopopulismo de Ponta Grossa em relação ao de Londrina. Belinatti não contou com uma crise tão profunda na elite dirigente para se transformar em candidato à prefeitura de Londrina, como Jocelito Canto em Ponta Grossa.

A eleição de Canto é, em grande medida, uma conseqüência da incapacidade da elite política tradicional de Ponta Grossa em identificar a sua própria decadência como representante pública. Se a vitória da oposição em 1996 deveu-se ao esgotamento do grupo político até então hegemônico e de suas práticas administrativas, então por que o escolhido como substituto não foi o candidato do PT? O partido vinha disputando as eleições municipais desde 1982. Tinha ficado em terceiro lugar nas eleições de 1988 e 1992 para prefeito, com 19,4\% dos votos válidos. Possuía desde 1989 uma vaga na Câmara de vereadores. Tinha um representante local na Câmara Federal, o deputado

\footnotetext{
15 O município havia perdido seu parque agropecuário no final do governo Otto Cunha e passou mais de dez anos sem um local apropriado para realizar feiras e exposições do setor rural, o que também demonstra o afastamento do grupo de pressão pecuarista do centro das decisões políticas locais.
} 
Padre Roque (eleito em 1994), e um na assembléia legislativa, o deputado Péricles de Holleben Melo (também eleito em 1994), ambos com experiências eleitorais anteriores e bases políticas organizadas no sindicalismo e movimentos sociais, principalmente nas diretorias de associações de moradores de bairros. O PT não seria o substituto natural dos governos municipais anteriores a 1996? Não.

Caso não tivesse surgido Jocelito Canto, provavelmente uma parte da dissidência do grupo hegemônico apoiaria a candidatura petista - como aconteceu em 1996 - e aumentaria suas chances de vitória eleitoral. Mas a existência de uma alternativa, aliada a fatores históricos, fizeram com que a preferência dos eleitores recaísse no candidato populista e não no do PT.

As bases sociais do PT em Ponta Grossa não cresceram na proporção necessária para garantir uma vitória eleitoral para prefeito em 1996. O município viveu quase duas décadas de estagnação econômica, o que impediu o crescimento da organização dos trabalhadores através dos sindicatos. O sindicalismo é o principal braço de intermediação do PT junto aos eleitores e, onde ele não está bem enraizado nas classes trabalhadoras, os candidatos do partido têm dificuldade em apresentar suas propostas.

O fato é que nos governos não-populistas, o Partido dos Trabalhadores estava presente no cenário, representado principalmente pelo candidato a prefeito, Péricles de Holleben Mello, e não conseguiu fazer com que as demandas sociais fossem atendidas. Logo, o eleitorado de baixa renda não tinha motivos para acreditar que uma prefeitura administrada pelo PT resolveria os problemas emergenciais da comunidade, não identificados pelas elites hegemônicas. O único candidato realmente novo no cenário e que se mostrava capaz de resolver os principais problemas das classes baixas sem parecer artificial foi Jocelito Canto. Por isso a opção do eleitorado recaiu sobre ele e não sobre o PT naquela eleição.

Essa identificação do PT com a crise local tem maior poder explicativo do que o possível medo dos eleitores de uma sociedade conservadora sentiriam em relação ao candidato do Partido dos Trabalhadores. Isso porque em 1996 Péricles de Mello foi o segundo colocado na disputa, com $31,9 \%$ dos votos válidos, ou seja, quase um 
kço do cleitorado. Quatro anos depois, em 2000, Péricles de Mello conseguiu se cleger prefeito de Ponta Grossa como candidato do PT quie fies allianças com o empresariado local ${ }^{16}$.

()s resultados das eleições de 1996 mostram um avanço significativo na aceitação das propostas do PT em Ponta Grossa. Tanto que, em 2000, o partido conseguiu chegar à prefeitura da cidade. Mas antes disso, a crise do discurso hegemônico e o surgimento de um outsider da política permitiram o sucesso eleitoral do neopopulismo na política local. Essas condições sociais, aliadas à difusão do discurso mudancista através do Rádio, foram o que promoverau Jocelito Canto a candidato viável para a prefeitura da cidade.

\section{O rádio e a votação de Jocelito Canto}

Jocelito Canto conseguiria manipular as vontades eleitorais das massas a ponto de vencer uma eleição em todas as classes sociais caso o seu programa de rádio fosse ouvido em toda a cidade? Pesquisas periódicas realizadas pelo Ibope (Instituto Brasileiro de Pesquisas e Estatísticas), encomendadas pelas próprias rádios locais mostram que a Garagem da Esperança não era líder de audiência em Ponta Grossa em

\footnotetext{
${ }^{16}$ Apesar do Partido dos Trabalhadores apresentar todas as limitações já citadas, que impediram sua vitória eleitoral em 1996, é preciso ressaltar que do ponto de vista político foi o partido que mais avançou nas eleições de 1996 em Ponta Grossa. Pela primeira vez seu candidato a prefeito deixou a terceira posição para passar ao segundo lugar sem fazer alianças e concessões a outros partidos políticos com representatividade. Péricles Mello ficou 12 mil votos à frente de Plauto Miró Guimarães Filho - representante da elite política tradicional. A bancada do PTna Câmara Municipal triplicou, subindo de uma para três cadeiras de um total de 21 . Ficou acima da bancada do PSDB, partido do prefeito eleito, que conseguiu preencher apenas duas vagas. O PT igualou seu número de vereadores ao do PMDB, partido mais organizado e com maior número de filiados no município, e ao PFL em 1996. Naquelas eleições o partido contou com o apoio de parte da elite econômica e de setores dos profissionais liberais - principalmente médicos - que não conseguia sensibilizar em campanhas eleitorais. Essa aproximação de integrantes de camadas sociais superiores ao PT de Ponta Grossa é um indicativo do realinhamento político na cidade. Além disso, profissionais liberais apresentam, normalmente, maiores resistências à aceitação do discurso populista de solução fácil para todos os problemas sociais.
} 
1996. Se o radialista que não é campeão de audiência consegue maioria de votos em uma cidade, devem-se procurar outras explicações para o sucesso eleitoral do neopopulismo, tais como as apontadas por Weffort (1989) para os fenômenos clássicos do populismo: massificação de amplas camadas da sociedade e perda de representatividade da classe dirigente aliados ao surgimento de um novo líder carismático. Assim, a Rádio seria um instrumento de contato entre o líder carismático e as massas, sem influência nos dois fatores anteriores.

As pesquisas de audiência apontam que a média de ouvintes diários de todos os programas matinais (a Garagem da Esperança começa às 6 h e segue até às $9 \mathrm{~h} 30$ ) das rádios de Ponta Grossa era de cerca de 60.000 pessoas em 1996. Isso representa menos de um quarto do total da população do município. A emissora líder de audiência em 1996 no horário matinal era a Rádio Central do Paraná e o programa do apresentador Rogério Serman, que tinha médias de $23 \%$ da preferência (cerca 15.000 ouvintes). Em segundo lugar vinha a Rádio Difusora, com o programa Garagem da Esperança, que ficava na casa dos $12 \%$ da preferência (cerca de 8.000 ouvintes). Em terceiro aparecia a Rádio Clube, $\operatorname{com} 7 \%$ da preferência (5.000 ouvintes).

Uma das principais características do programa de Jocelito Canto eram as doações diárias a pessoas com as mais variadas necessidades. Pelos registros da própria Garagem da Esperança, entre 1992 e 1996 foram atendidas 19 mil pessoas no programa comandado por Jocelito Canto $^{17}$. Considerando que uma parte das pessoas atendidas busca auxílio do radialista periodicamente (há carentes que estão nesse tipo de programa toda semana em busca de remédio, um colchão novo, emprego, etc.) o número de pessoas beneficiadas ficou perto da metade dos 19 mil. Tanto a audiência média, quanto o número de pessoas atendidas pelo programa de Jocelito Canto ficaram muito abaixo do número de votos obtidos pelo radialista em 1996 (54.363 votos).

O desempenho de Rogério Serman (PTB) nas eleições de 1996 é outro indicador do peso que um programa radiofônico tem para a eleição de um candidato. Além de radialista com mais de 20 anos de profissão em Ponta Grossa, ele foi vereador na legislatura de 1992 e 1996.

17 Dados fornecidos pelo radialista ao autor. 
Mantinha a maior audiência matinal em programas AM da cidade e, além disso, pesquisas qualitativas do Ibope apontavam-no como o radialista de maior credibilidade entre os apresentadores de programas em rádios $\mathrm{AM}$ da cidade. Serman foi candidato à reeleição em $1996 \mathrm{e}$ começou a campanha praticamente eleito. Afinal de contas eram 15.000 ouvintes diários, em média. Acontece que ele fez "apenas" 2.142 votos. Como seu partido, o PTB, conseguiu cociente eleitoral para uma vaga na Câmara Municipal e o candidato mais votado do PTB naquela eleição, com 3.791 votos, foi o médico Pascoal Adura; Serman não conseguiu se reeleger para a Câmara Municipal. É verdade que ele fez mais votos que 18 dos 21 eleitos e ficou fora da Câmara por distorções do sistema eleitoral brasileiro. Mas a relação entre o número de votos que teve e a audiência que mantinha à época da campanha deixa claro que a transformação de ouvinte em eleitor de candidato/radialista não é automática nem mesmo para cargos legislativos; menos ainda em disputas majoritárias.

A análise do resultado da eleição de 1996 em Ponta Grossa, por zonas eleitorais, comprova a fragilidade da explicação de manipulação de classes sociais baixas em favor da eleição do candidato/radialista, portador do discurso populista para a prefeitura local. Os números oficiais do TRE (Tribunal Regional Eleitoral) apontam para a mesma normalidade dos resultados das eleições anteriores. A única mudança foi no posicionamento dos representantes de cada agrupamento político na preferência dos eleitores.

\section{Tabala 3}

Resultados por zonas eleitorais em Ponta Grossa em 1996

\begin{tabular}{|c|c|c|c|c|c|c|}
\hline \multirow[b]{2}{*}{ CANDIDATO } & \multicolumn{6}{|c|}{ ZONAS ELEITORAIS } \\
\hline & $14^{a}$ & $15^{a}$ & $139^{a}$ & $197^{a}$ & $198^{a}$ & |TOTAL \\
\hline Jocelito Canto & $\begin{array}{l}9.560 \\
(36,15 \%)\end{array}$ & $\begin{array}{l}9.627 \\
\left(33,78^{\circ}\right)\end{array}$ & $\begin{array}{l}16: 119 \\
\left(52,74 \dot{c}^{\circ}\right)\end{array}$ & $\begin{array}{l}9,367 \\
\left(37,730_{0}\right)\end{array}$ & $\begin{array}{l}9.690 \\
(51,14 \%)\end{array}$ & $\begin{array}{l}54.363 \\
(42,04 \%) .\end{array}$ \\
\hline Péricles de Holleben Melo & $\begin{array}{l}9.342 \\
(35,32 \%)\end{array}$ & $\begin{array}{l}9,469 \\
(33,22 \%)\end{array}$ & $\begin{array}{l}8.142 \\
(26,64 \%)\end{array}$ & $\begin{array}{l}8.753 \\
(35,25 \%)\end{array}$ & $\begin{array}{l}5,605 \\
(29,58 \%)\end{array}$ & $\begin{array}{l}41,311 \\
(31,95 \%)\end{array}$ \\
\hline Plauto Miró G. Filho & $\begin{array}{l}6.954 \\
(26,30 \%)\end{array}$ & $\begin{array}{l}8.858 \\
(31,08:)\end{array}$ & $\begin{array}{l}5.757 \\
(18,83 \%)\end{array}$ & $\begin{array}{l}6,232 \\
(25,10 \%)\end{array}$ & $\begin{array}{l}3,287 \\
(17,35 \%)\end{array}$ & $\begin{array}{l}31,088 \\
(24,04 \%)\end{array}$ \\
\hline José Penkoski & $\begin{array}{l}590 \\
(2,23 \%)\end{array}$ & $\begin{array}{l}547 \\
(1,92 \%)\end{array}$ & $\begin{array}{l}548 \\
(1,79 \%)\end{array}$ & $\begin{array}{l}477 \\
\left(1,922_{0}^{\circ}\right)\end{array}$ & $\begin{array}{l}366 \\
(1,93 \%)\end{array}$ & $\begin{array}{l}2.528 \\
(1,95 \%)\end{array}$ \\
\hline
\end{tabular}


Em 1996, o município de Ponta Grossa estava dividido em cinco zonas eleitorais. Por se tratar de um município antigo, as novas zonas eleitorais foram delimitando as áreas de crescimento da cidade. As duas zonas eleitorais mais antigas, $14^{\mathrm{a}}$ e $15^{\mathrm{a}}$, abrangem o que hoje é o centro da cidade. Segundo amostragem por domicílios feita pelo IBGE em 1996, o perfil médio do eleitor alistado nas seções eleitorais destas zonas é de classe média a alta, de escolarização média ou superior. A maioria dos chefes de família é de empresários, profissionais liberais ou funcionários de carreira em empregos estáveis. A média de idade fica acima das outras zonas eleitorais. Nessas duas zonas votam os aposentados da classe média, comerciantes, professores universitários, funcionários da burocracia local e estudantes. Entre os candidatos, Plauto Miró Guimarães Filho, José Penkoski e Péricles Holleben votam nessas zonas eleitorais.

Existem outras duas zonas eleitorais urbanas no município, a $139^{a}$ e a $197^{a}$. A primeira está localizada na região norte da cidade e periferia, principalmente no bairro de Santa Paula e adjacências. O perfil do eleitorado dessa região é de trabalhadores assalariados. Nível médio de escolaridade e média de idade jovem. Apesar de ser periférica, essa região tem melhores perspectivas econômicas. É nela que se dá um dos maiores entroncamentos rodoferroviários do sul do Brasil, ligando a capital ao norte do Estado e a outras regiões do país. Isso estimula o desenvolvimento da atividade de transportadoras de cargas, comércio de peças de caminhões e prestação de serviços nesta área. O distrito industrial Cyro Martins, onde são feitos os novos investimentos industriais no município, encontra-se nessa área. A manutenção da atividade econômica fez com que os trabalhadores assalariados desta parte da cidade mantivessem uma atividade política mais ativa. Apesar disso, o nível de escolaridade continua sendo, em média, o segundo grau completo ou incompleto e a população jovem tem importância significativa no total da região.

A $197^{\mathrm{a}}$ zona eleitoral é a menor em área de abrangência. Ela engloba a região do Jardim Carvalho, próximo da área central da cidade. O poder aquisitivo dos eleitores da $197^{a}$ é de médio a alto. O jardim Carvalho é o bairro onde moram empresários e profissionais liberais de classe média da cidade. 
A última zona eleitoral de Ponta Grossa, a 198 a abrange toda a zona rural (lo municipio e o bairro de Uvaranas. É a maior em número de elcitores. A região de Uvaranas é considerada a "esquecida" da cidade. () descenvolvimento social e econômico dessa área ficou abaixo da média municipal nas últimas duas décadas. Boa parte de estudantes de classe média baixa sem perspectiva de colocação no mercado de trabalho mora nessa região.

A população rural é minoria, com cerca de $12 \%$ do total de eleitores. Tem média de idade superior à média urbana e com perfil social mais conservador. A renda média familiar na zona rural é considerada baixa.

Nas eleições de 1996 foram computados 129.290 votos válidos para prefeito. Jocelito Canto ficou com 54.363 votos, ou $42,02 \%$ do total. Péricles de Holleben Mello teve 41.311 votos, ou 31,95\%. Plauto Miró Guimarães Filho terminou a campanha com 31.088 votos válidos, ou $24,04 \%$ do total apurado. E José Penkoski fez 2.528 votos válidos, ou $1,95 \%$ do total.

Caso o radialista Jocelito Canto tivesse mesmo o poder de manipulação irrestrito das massas através do trabalho assistencialista da Garagem da Esperança e de seus discursos populistas contra os poderosos locais, sua votação teria sido esmagadora na $139^{\mathrm{a}}$ e $198^{\mathrm{a}}$ zonas eleitorais, onde se encontra a maioria dos excluídos e integrantes das classes sociais baixas. O normal também seria que ele perdesse a disputa para o candidato representante do tradicionalismo político na $14^{\mathrm{a}}$ e $15^{\mathrm{a}}$ zonas eleitorais e na $197^{\mathrm{a}}$ zona, onde vivem os "novos ricos", naturalmente avessos ao populismo eleitoral e assistencialismo social feito pelo radialista. Apenas as classes sociais mais baixas estariam sujeitas à manipulação, pois elas é que ouvem os programas radiofônicos popularescos das emissoras AM, como o de Canto. Porém, fenômenos neopopulistas, assim como os populistas, não surgem em razão da manipulação das vontades eleitorais, ele também acrescenta conteúdos de cidadania como mostra Weffort (1989).

De acordo com a análise tradicional da distribuição geográfica do voto, Péricles de Mello teria chances de disputar a liderança com Jocelito Canto na $139^{\mathrm{a}}$, onde a atividade dos sindicatos é mais significativa e há maior participação do PT. E Plauto Miró deveria ser o 
preferido do eleitorado das classes altas, nas duas zonas eleitorais do centro da cidade, e na do Jardim Carvalho. Não foi o que aconteceu. Jocelito Canto teve maioria de votos em todas as cinco zonas eleitorais. Péricles de Mello ficou em segundo lugar nas cinco zonas eleitorais. Plauto Miró ocupou a terceira posição em todo o município. Houve quase uma repetição do volume de votos percentuais dados aos candidatos de $1992^{18}$.

A decomposição do total de votos de cada candidato por zonas eleitorais e sua participação no conjunto da votação dos concorrentes reafirma que, além de não existir a manipulação tão propalada dos eleitores pelo discurso populista, o candidato Jocelito Canto venceu porque foi beneficiado pela falta de políticas públicas de desenvolvimento econômico para a região sul da cidade durante os governos não-populistas.

Jocelito Canto fez $36,15 \%$ dos votos válidos da $14^{\mathrm{a}}$ zona eleitoral, $33,78 \%$ na $15^{\mathrm{a}}, 52,74 \%$ na $139^{\mathrm{a}}, 37,73 \%$ na $197^{\mathrm{a}}$ e $51,14 \%$ dos votos da $198^{a}$. Nessa última, justifica-se a quantidade expressiva de votos por se tratar do eleitorado rural. A presença dos candidatos tradicionais nas regiões rurais é muito pequena, por falta de políticas agrícolas específicas e identificação com essas populações. Como se tratava da menor porcentagem de votos do município, mesmo que a aceitação de Canto fosse maior, teria pouca influência no resultado final. Em outras três zonas eleitorais ele manteve a regularidade com cerca de um terço dos votos válidos. Nas duas da periferia, as mais excluídas e sem políticas públicas que atendessem as demandas sociais, Canto ultrapassou a metade dos votos válidos.

O fato relevante é que o radialista conseguiu maioria simples nas áreas com eleitores de perfil tradicional e de classe social alta ou média. Estas regiões representaram dois terços (79.776 votos) dos votos válidos na eleição de 1996. As zonas eleitorais da periferia e áreas rurais, onde Canto teve maioria absoluta, representaram um terço

\footnotetext{
${ }^{18}$ Esse tipo de exercício analítico da interpretação da distribuição geográfica do voto não foi realizado para o caso de Londrina porque nos anos 70 s a cidade possuía apenas duas zonas eleitorais ( 41 e 42 ). Elas dividiam o município ao meio, distribuindo de maneira igualitária o centro e a periferia do município, o que impossibilita a identificação de características particulares do perfil do eleitor de cada uma delas.
} 
(49.484) do total de votos válidos. A vitória de Canto deveu-se aos votos da classe média e alta, não aos da classe baixa.

Péricles Holleben manteve uma linearidade de votos em todas as zonas eleitorais. Fez $33,32 \%$ dos votos válidos da $14^{\mathrm{a}}$ zona, $33,22 \%$ na $15^{\mathrm{a}}$ zona, $26,64 \%$ na $139^{\mathrm{a}}, 35,25 \%$ na $197^{\mathrm{a}}$ zona e $29,58 \%$ na $198^{\mathrm{a}}$ zona eleitoral. Teve uma participação um pouco menor na zona rural que a sua média geral. Mas caiu ainda mais na região de Uvaranas. Como não houve desenvolvimento econômico nessa região, a organização das classes trabalhadoras e dos microempresários foi incipiente, dificultando a aceitação do Partido dos Trabalhadores. A organização sindical e os movimentos sociais são os maiores instrumentos de contato com os eleitores que o PT possui. Péricles de Holleben conseguiu seus melhores desempenhos na $14^{\mathrm{a}}$ zona, região dos profissionais liberais dissidentes da elite política, e na $197^{\circ}$, área com maior índice de organização sindical do município. O que demonstra que o PT continua dependendo das organizações sindicais e classistas para a difusão de suas propostas ao conjunto da sociedade ${ }^{19}$.

As votações de Plauto Miró Guimarães oscilaram entre as zonas eleitorais mais do que as dos outros candidatos. Na $14^{\mathrm{a}}$ zona eleitoral ele teve $26,3 \%$ dos votos válidos, $31,08 \%$ na $15^{\mathrm{a}}, 18,83 \%$ na $139^{\mathrm{a}}, 25,01 \%$ na $197^{\mathrm{a}}$ e $17,35 \%$ na $198^{\mathrm{a}}$. Seu pior desempenho foi na zona rural. No perímetro urbano, teve maior rejeição na área de Uvaranas. Manteve as mesmas médias entre o perímetro norte e a região de votação dos profissionais liberais. Foi melhor votado na região mais tradicional da cidade, a $15^{\mathbf{a}}$ zona eleitoral. As oscilações de preferência eleitoral de Plauto Miró são maiores que as dos outros dois candidatos, indicando que, se houve tentativa de manipulação de segmentos específicos do eleitorado, isso aconteceu na campanha do candidato da continuidade e não nas de oposição.

José Penkoski conseguiu a média de $1,95 \%$ dos votos válidos em todas as zonas eleitorais, o chamado voto de protesto ou irresponsável.

Do total de votos de Jocelito Canto, $17,58 \%$ foi na $14^{\mathrm{a}}$ zona eleitoral, $17,70 \%$ na $15^{a}, 29,6 \%$ na $139^{a}, 17,23 \%$ na $197^{a}$ e $17,82 \%$ na $198^{a}$ zona. Apresentou uma linearidade só quebrada na região de Uvaranas,

11) Some-se às entidades de classe que já dominava a aproximação do partido aos empresários e aos movimentos religiosos locais em 2000 para que o PT conseguisse alcançar os votos necessários para eleger o prefeito de Ponta Grossa em 2000. 
o que invalida as explicações de vitória pela simples manipulação de segmentos específicos do eleitorado. A distribuição do total de votos de Péricles Holleben foi a seguinte: $22,61 \%$ na $14^{\mathrm{a}}$ zona eleitoral, $22,92 \%$ na $15^{a}, 19,70 \%$ na $139^{a}, 21,18 \%$ na $197^{a}$ zona e $13,56 \%$ na $198^{a}$. Ele manteve o mesmo desempenho nas regiões do eleitorado formado pelos profissionais liberais e pelos trabalhadores sindicalizados. Teve menos densidade eleitoral na zona rural e em Uvaranas. A distribuição dos votos de Plauto Miró entre as diversas regiões da cidade foi a seguinte: $22,36 \%$ do total na $14^{\mathrm{a}}$ zona eleitoral, $28,49 \%$ na $15^{\mathrm{a}}, 18,51 \%$ na $139^{\mathrm{a}}$, $20,04 \%$ na $197^{\mathrm{a}}$ e $10,57 \%$ na $198^{\mathrm{a}}$. A maior importância quantitativa nos votos de Plauto Miró foi na área mais tradicional da cidade. Seu pior desempenho foi na zona rural.

A distribuição dos votos aos candidatos em 1996 não se deveu apenas à campanha eleitoral daquele ano. Analisando o desempenho dos candidatos com perfil não-populista do governo e da oposição nos anos 80 s e 90 s na cidade, é possível perceber um gradativo crescimento da insatisfação eleitoral com a elite hegemônica e um favorecimento das candidaturas alternativas antes mesmo do surgimento da liderança neopopulista. Assim como em Londrina, o índice de avanço dos votos brancos e nulos foi continuamente positivo no período anterior à eleição de Canto. Boa parte da explicação para a eleição do radialista/populista em 1996 encontra-se na década que antecedeu a chegada de Canto à prefeitura.

Uma informação importante sobre o resultado eleitoral de 2000 é que o candidato Jocelito Canto ficou com $41,42 \%$ dos votos válidos naquele ano, menos de um ponto percentual de diferença da votação que fizera em 1996, quando foi vitorioso $(42,04 \%)$. Isso demonstra que o eleitorado de Canto foi praticamente o mesmo nas duas eleições. $O$ que mudou foi o percentual de aceitação do candidato do PT, que passou de $31,95 \%$ dos votos válidos em 1996 para 49,72\% em 2000 . Com a ausência de um candidato que representasse o grupo tradicional na política, o eleitor tradicional dos candidatos não-populistas optou por votar no representante do PT ao invés de votar no neopopulista. Apesar das diferenças ideológicas entre Péricles Mello e os representantes dos governos dos anos 80 e 90 na cidade, o perfil social do candidato petista se aproxima mais do perfil não-populista do que 
de Jocelito Canto. Mesmo sem pertencer a uma família integrante da elite econômica local, Péricles Mello é nascido em Ponta Grossa, professor universitário e tradicional ativista político local.

A comparação entre os resultados eleitorais de 1996 e 2000 permitem afirmar que o candidato de perfil neopopulista manteve o eleitorado no período de sua administração, mas não conseguiu ampliar sua capacidade de representação popular, o que inviabilizou sua reeleição. Isso, apesar dele ter-se mantido como radialista durante os quatro anos como prefeito. É possível acreditar que, se houver uma nova crise do discurso hegemônico na cidade e a manutenção da liderança neopopulista local através de eleições futuras para cargos legislativos, Jocelito Canto possa voltar a ser eleito prefeito de Ponta Grossa, mas essa será uma outra história.

\section{Conclusão}

O esgotamento de um perfil de representantes políticos locais, a crise do discurso hegemônico gerada por uma crise social mais ampla, o surgimento de um outsider como alternativa política e a manutenção de eleições periódicas são condições necessárias para o surgimento do fenômeno conhecido por neopopulismo político. O mérito dos neopopulistas é ter capacidade para perceber que o discurso tradicional e as elites políticas hegemônicas caíram em descrédito, aproveitaremse dessa oportunidade para convencer o conjunto da sociedade sobre as vantagens da "mudança" e conseguirem apresentar-se como a melhor alternativa política naquele momento, utilizando para isso os instrumentos de formação da imagem pública que tenham à disposição, inclusive os Meios de Comunicação de Massa.

Considerar que a eleição majoritária de um comunicador profissional deva-se apenas ao seu trabalho como comunicador é desprezar o que há de substancial no processo de decisão eleitoral. A novidade na democracia de público está na forma como candidato e eleitor "encontram-se" na esfera pública. As condições sociais para definição do voto, suas potencialidades e limitações, continuam tendo papel fundamental na definição do comportamento do eleitor. Jocelito 
Canto não foi eleito de sua cidade apenas por ser competente comunicador de massa. O rádio o credenciou como candidato ao servir como instrumento propagador de um novo discurso, mas não assegurou, antecipadamente, sua vitória majoritária. Tanto que, após sua eleição para a prefeitura, perdeu a exemplaridade, não conseguiu ampliar a capacidade de representação pública e sofreu uma derrota eleitoral, mesmo tendo continuado em seu programa radiofônico quando prefeito.

O assistencialismo aos carentes de Canto em programa de rádio teve menos importância nos resultados das eleições majoritárias dele do que o aproveitamento das pré-disposições conjunturais dos eleitores. O fortalecimento da dissidência política e os déficits na implementação de políticas públicas, representado esquematicamente pelo sistema Top and Down de definição de políticas públicas, mostram que a substituição do grupo hegemônico no poder local faz parte de um processo de desgaste natural das elites políticas, possível de acontecer em qualquer tipo de democracia. Portanto, não devendo a fenômenos de manipulação das massas através dos meios de comunicação como o Rádio. Em ambos os casos havia um comunicador profissional da cena política no ápice do processo de desgaste das elites dirigentes locais.

É um equívoco vincular a eleição de um político/comunicador com o fato de ele ser um radialista com bons índices de audiência, principalmente em disputas para cargos majoritários. Mais importante que saber utilizar com habilidade este "instrumento" de difusão de um discurso eleitoral que se chama rádio, é a capacidade de adequação do conteúdo do discurso difundido às expectativas do eleitorado. Não se trata aqui de tentar negar a importância dos meios de comunicação para a política contemporânea, mas sim de uma relativização de sua importância nos processos de decisão do voto, considerando outros fatores sociais, como os responsáveis pelo crescimento de amplas crises no conjunto da sociedade e de desgastes das elites hegemônicas. Assim como uma festa religiosa não é apenas um acontecimento religioso, uma eleição é mais do que um evento político propriamente dito. Ela é um fenômeno social e como tal deve ser analisada a partir de um contexto social amplo.

Pode-se afirmar que apesar dos sucessivos anúncios de morte, o populismo político, atualizado pela denominação neopopulista, não sucumbiu com o fim das transições das sociedades rurais para as 
sociedades urbanas. Ele continua vivo e continuará assim, independente de quais forem as características e predisposições sedimentadas das sociedades. Também não se deve considerar a prática personalista da política como uma característica exclusiva do populismo. Historicamente, a relação de balcão entre representantes e representados na política brasileira antecede as primeiras ocorrências populistas. O que aconteceu foi uma adequação do personalismo coronelista rural ao populista urbano. O populismo eleitoral é uma alternativa em democracias que estejam passando por crises - estruturais ou conjunturais nas esferas econômica, social ou política, onde as elites tradicionais tenham perdido a capacidade de identificar as demandas sociais e quando houver uma liderança carismática disposta a se aproveitar da crise do discurso hegemônico para se candidatar aos postos de tomada de decisão política.

\section{Referências Bibliográficas}

ANGElL, Alan. Populismo e mudança política: o caso da Colômbia. In: TABAK, Fanny (Org.) Ideologias - Populismo. Rio de Janeiro: Editora Eldorado, 1973.

BARBOSA, Maria Lucia Victor. O Voto da Pobreza e a Pobreza do Voto : a ética da malandragem. Rio de Janeiro: Jorge Zahar/UEL, 1988.

HAM, Cristopher; HILL, Michael. The Policy Process in the Modern Capitalist State. 2.ed. Londres: Harvester Wheatsheaf, 1993.

HALEBSKI, Sandor. Sociedade de Massa e Conflito Político. Rio de Janeiro: Jorge Zahar, $1978^{\circ}$.

IBGE. Censo Demográfico 1950-2000. Rio de Janeiro, 2000.

IBGE. Pesquisa nacional por amostragem domiciliar. Ponta Grossa,1996.

INCISA, Ludovico. Dicionário de Política. 11.ed. Brasília: UNB, 1998.

IPARDES. Perfil econômico dos Municípios do Paraná. Curitiba., 1998. 
JIMENEZ, Alfredo Ramos. Las Formas Modernas de la Política : estudio sobre la democratización de América Latina. Mérida: Centro de Investigaciones de Política Comparada, 1997.

MANIN, Bernard. As metamorfoses do governo representativo. Revista Brasileira de Ciências Sociais, ano 10, n.29, p.5-34, 1995.

SILVA, Maurício F. Quem me elegeu foi o rádio. São Paulo: Ed.Olho d' Água, 2000.

TELLA Di, Torcuato. Populismo e Reforma Na América. In: CARDOSO,

Fernando Henrique; MARTINS, Carlos Estevam. Política e Sociedade. 2.ed. São Paulo. Companhia Editora Nacional. 1983. v.1.

WEFFORT, Francisco. O populismo na política brasileira. 4.ed. Rio de Janeiro: Paz e Terra, 1989.

\section{Abstracts}

The interest for the study of the effects of the mass communication in the contemporary societies, especially in the electoral processes, it is growing. It has been common to verification of the existence of an interdependence relationship among the propagation of the political speech through the broadcastings and the phenomenon of the political populism. The present work analyzes the importance of the Radio for the mayor's of a broadcaster/polític election in the city of Ponta Grossa. Through the study of the characteristics of the local political elites. of the effects of the implanted public politics and of the crises of the situation for the which passed the voters of that city, it is possible to identify the origin of the acceptance of the speech neopopulist. Being like this, it can be said that the phenomenon broadcaster/polític is not born in the waves of the radio, but through them it gets to spread the idea of change.

Key words: radio, elections, neopopulism, political elites, local power. 


\section{Anexos}

\section{Anexo 1}

\section{Resultado da eleigâo para prefeito de Ponta Grossa em 1982}

\begin{tabular}{l|c|c|c} 
CANDIDATO & PARTIDO & N'DE votOS & \% DE vOTOS \\
Otto SantosCunha & PMDB & 28.509 & 33,6 \\
José Carlos do Amaral & PMDB & 20.201 & 23,8 \\
CyroMartins & PDS & 15.724 & 18,5 \\
Plauto Miró Guimarães & PDS & 10.884 & 12,8 \\
César Femandes Pilati & PDS & 337 & 0,4 \\
Brasil Ribas Neto & PTB & 1.374 & 1,6 \\
AntonioMaier & PTB & 276 & 0,3 \\
Périclesde HollebenMelo & PT & 650 & 0,7 \\
& & & 5,4 \\
\hline Votosembranco & & 4.617 & 2,5 \\
\hline Votosnulos & & 2.168 & 92,0 \\
\hline Votosválidos & & 77.955 & \\
\hline Total votantes & & 84.740 & \\
\hline
\end{tabular}

Fonte: TRE - Paraná

Anexo 2

Resultado da eleiça para prefeito de Ponta Grossa em 1988

\begin{tabular}{l|l|l|l} 
CANDIDATO & PARTIDO & No DE vOTOS & $\%$ DE vOTOS \\
PedroWosgrauFilho & PDC & 46.457 & 46,7 \\
Djalmade AlmeidaCesar & PMDB & 27.416 & 27,5 \\
LuizCarlosZuk & PDT & 17.430 & 17,5 \\
Silvio Femandes da Silva & PT & 8.033 & 8,3 \\
& & & \\
& Votosembranco & 9.580 & 8,5 \\
\hline & Votosnulos & 3.281 & 3,0 \\
\hline & Votosválidos & 99.336 & 88,5 \\
\hline & Total votantes & 112.197 & \\
\hline
\end{tabular}

Fonte: TRE - Paraná 


\section{Anexo 3}

\section{Resultado da elelgấo para prefeito de Ponta Grossa em 1992}

\begin{tabular}{l|l|l|l} 
CANDIDATO & PARTIDO & N' DE votos & \% DE votos \\
Paulo Cunha Nascimento & PDC & 45.503 & 41,9 \\
Djalma de Almeida Cesar & PMDB & 36.209 & 33,3 \\
Padre Roque Zimermann & PT & 21.097 & 19,4 \\
Adail Inglês & PTB & 5.709 & 5,4 \\
& & & \\
& Votosembranco & 7.245 & 5,8 \\
\hline & Votosnulos & 7.883 & 6,4 \\
\hline & Votosválidos & 108.518 & 87,7 \\
\hline & Total votantes & 123.646 & \\
\hline
\end{tabular}

Fonte: TRE - Paraná

Anexo 4

Resultado da eleição para prefeito de Ponta Grossa em 1996

\begin{tabular}{l|l|l|l} 
CANDIDATO & PARTIDO & No DE votOS & $\%$ DE vOTOS \\
Jocelito Canto & PSDB & 54,363 & 42,0 \\
Péricles Holleben Melo & PT & 41.311 & 31,9 \\
Plauto Miró Guimarães Filho & PFL & 31.088 & 24,0 \\
José Penkoski & PSC & 2.528 & 1,9 \\
& & & \\
& Votosem branco & 1.059 & 0,8 \\
\hline & Votosnulos & 3.956 & 2,9 \\
\hline & Votosválidos & 129.190 & 96,3 \\
\hline & Totalvotantes & 134.305 &
\end{tabular}

Fonte: TRE - Paraná 
Anexo 5

Licantindo do dolfalo para prefeito de Ponta Grossa em 2000

\begin{tabular}{l|l|l|l} 
CANDIDATO & PARTIDO & NDE vOTOS & \% DE vOTOS \\
Péricles Holleben Melo & PT & 72.583 & 49,7 \\
Jocelito Canto & PSDB & 60.459 & 41,4 \\
Carlos Tavarnaro & PFL & 6.762 & 4,6 \\
Wagner Menezes & PPS & 3.023 & 2,0 \\
José Penkoski & PSC & 2.857 & 1,9 \\
Rogério Marcondes & PRN & 279 & 0,2 \\
& & & 1,8 \\
\hline & Votosembranco & 2.813 & 3.8 \\
\hline & Votosnulos & 5.927 & 94.4 \\
\hline
\end{tabular}

Fonte: TRE - Paraná 